HortSCIENCE 27(2):185-186. 1992.

\title{
Freda: A New Tomato Parthenocarpic Hybrid
}

\author{
Joaquín Costa, Soledad Catalá, and Francisco Botella \\ Comunidad Autónoma de la Región de Murcia, Consejería de \\ Agricultura, Ganaderia y Pesca, Centro Regional de Investigaciones \\ Agrarias, Spain
}

\section{Fernando Nuez}

Departamento de Biotecnología, E. T. S. I. Agrónomos, Universidad Politécnica de Valencia, Spain

\section{Jesus Cuartero \\ Consejo Superior de Investigaciones Cientificas, La Mayora, Málaga, Spain}

Additional index words Lycopersicon esculentum, fruit quality, hormone

Auxin is commonly applied to facilitate fruit setting in tomato (Lycopersicon esculentum Mill.) grown during winter-spring on the Mediterranean coast. However, fruit quality is lost (puffiness, pointed blossom ends, etc.) with the use of auxin.

'Freda' is a commercial, fresh-market hybrid for winter growing and is suitable either for open field or greenhouse. 'Freda' is able to set seedless fruits at low temperatures without hormone applications.

Received for publication 12 Mar. 1990. Accepted for publication 31 Oct. 1991. The cost of publishing this paper was defrayed in part by the payment of page charges. Under postal regulations, this paper therefore must be hereby marked advertisement solely to indicate this fact.

\section{Origin}

'Severianin' (L. esculentum Mill.) was the source of parthenocarpy (Fig. 1). The genetic system that controls parthenocarpy of 'Severianin' is not clear. Some authors propose that parthenocarpy is conditioned by a

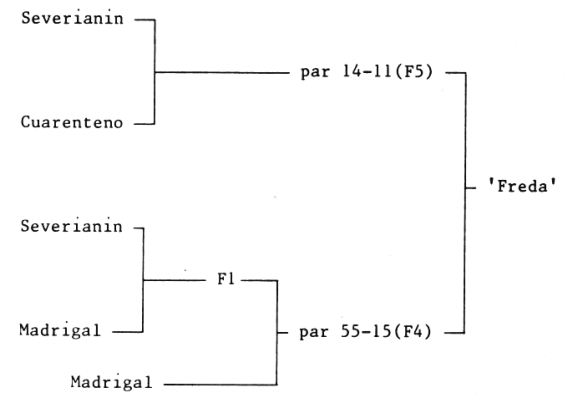

Fig. 1. Pedigree. of 'Freda'.

simple recessive gene (pat-2) (Nuez, 1986; Philouze and Maissonneuve, 1978) while other research supports a two recessive-gene model consisting of one major (pat-2) and one minor gene (mp) (Vardy, 1985).

'Cuarenteno' and 'Madrigal' are widely grown in southeastern Spain. They show an excellent adaptation to cultivation under this environment and produce medium to large fruits. Fruit equatorial diameter and fruit weight averages are, respectively, $7.8 \mathrm{~cm}$ and $260 \mathrm{~g}$ for 'Madrigal' and $6.3 \mathrm{~cm}$ and $110 \mathrm{~g}$ for 'Cuarenteno'.

Table 1. Comparative early (until 148 days after transplanting) and total yield, fruit weight average, and percentage of seedless fruits during winter-spring in southeastern Spain. ('Carpy' is a commercial parthenocarpic hybrid. 'Carmelo' and 'Vemone' are conventional and commercial hybrids.)

\begin{tabular}{|c|c|c|c|c|c|}
\hline \multirow[b]{2}{*}{ Cultivar } & \multicolumn{2}{|c|}{ Yield $\left(\mathrm{kg} \cdot \mathrm{m}^{-2}\right)$} & \multirow{2}{*}{$\begin{array}{l}\text { Fruit wt } \\
\text { (g) }\end{array}$} & \multicolumn{2}{|c|}{ Seedless fruits (\%) } \\
\hline & Early & Total & & Early & Total \\
\hline $\begin{array}{l}\text { Freda } \\
\text { Carpy } \\
\text { Carmelo } \\
\text { Vemone }\end{array}$ & $\begin{array}{l}2.6 \\
2.9 \\
0.6 \\
1.0\end{array}$ & $\begin{array}{l}12.8 \\
13.2 \\
10.2 \\
16.2\end{array}$ & $\begin{array}{r}144 \\
99 \\
105 \\
66\end{array}$ & $\begin{array}{c}93.0 \\
89.7 \\
0 \\
0\end{array}$ & $\begin{array}{c}53.3 \\
52.0 \\
0 \\
0\end{array}$ \\
\hline
\end{tabular}




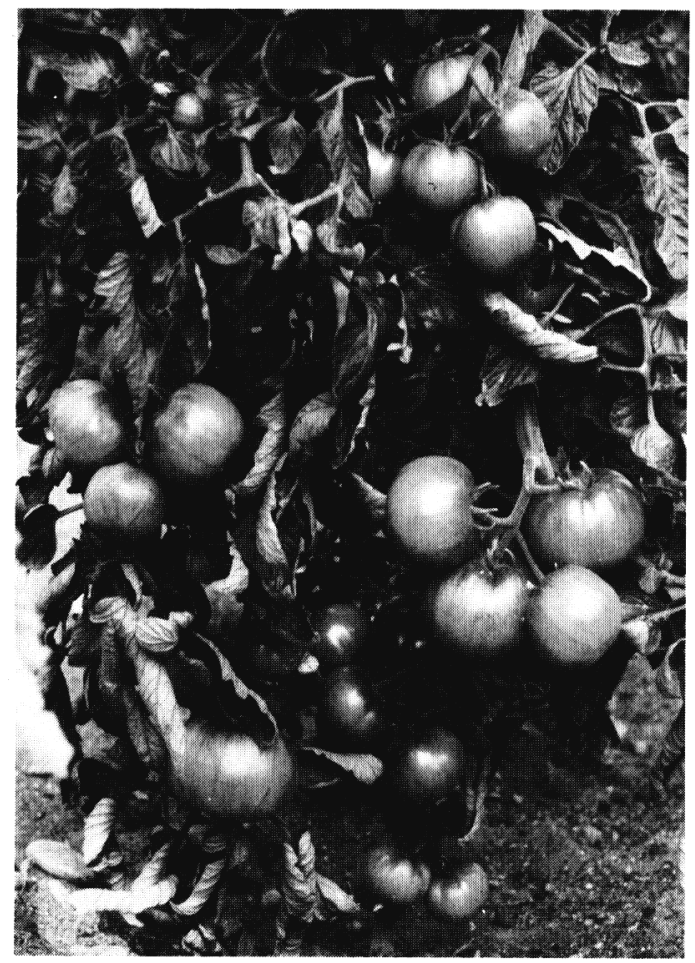

ribbed, have dark green shoulders, and are oblate (Fig. 2). The average fruit weight was $144 \mathrm{~g}$. The production was $\approx 13 \mathrm{~kg} \cdot \mathrm{m}^{-2}$ in winter without hormone treatment and $50 \%$ of the production was seedless fruit (Table 1).

\section{Availability}

'Freda' has been registered in the Instituto National de Semillas y Plantas de Vivero of Spain. A limited amount of seed stock will be available from J.C.

\section{Literature Cited}

Nuez, F., J. Costa, and J. Cuartero. 1986. Genetics of the parthenocarpy for tomato varieties 'Sub-Artic Plenty', '75/59' and 'Severianin'. Z. Pflanzenzüchtg. 96:200-206.

Philouze, J. and B. Maisonneuve. 1978. Heredity of the natural ability to set parthenocarpic fruits in a German line. Rpt. Tomato Genet. Coop. 28, 12.

Vardy, E. 1985. Genetics of parthenocarpy in tomato (Lycopersicon esculentum, Mill.) lines 'Severianin' and '75/59' and linkage of genes for parthenocarpy with morphological marker genes. MS Thesis, Faculty Agr., Hebrew Univ., Jerusalem.

Fig. 2. Fruits of 'Freda'.

Selection for parthenocarpy was done in a greenhouse during the coldest period of the year, when minima averaged 5.1C and maxima $23 \mathrm{C}$.

\section{Description}

Plant habit of 'Freda' is indeterminate. Fruits are red-orange when ripe, slightly 